\title{
Common Usability Problems on Educational Websites
}

\author{
Layla Hasan \\ Department of Management Information Systems \\ Zarqa University \\ Jordan
}

\author{
Emad Abuelrub \\ Commission for Academic Accreditation \\ Ministry of Higher Education \& Scientific Research \\ UAE
}

\begin{abstract}
This research employed the heuristic evaluation method to comprehensively evaluate the usability of three large public university websites in Jordan (Hashemite University, the University of Jordan, and Yarmouk University). The evaluation involves testing all pages related to the selected universities' faculties and their corresponding departments. A list of 34 specific types of usability problems, which could be found on a Jordanian university website, was identified.
\end{abstract}

Keywords- Usability, heuristic evaluation, educational websites, Jordan

\section{INTRODUCTION}

Usability has been defined as "the extent to which a product can be used by specified users to achieve specified goals with effectiveness, efficiency, and satisfaction in a specified context of use" [1]. Various usability evaluation methods have been developed to evaluate the usability of websites. The methods could be categorized into three categories, in terms of how the usability problems are identified, for example by evaluators, users, or tools. Evaluator-based methods are aimed at finding usability problems that users might encounter while interacting with an interface, from the evaluators' point of view. Heuristic evaluation is one of the most frequently evaluator-based usability evaluation methods. It involves having a number of evaluators assess the user interface, and judge whether it conforms to a set of usability principles, namely heuristics, [2]. The other usability evaluation methods, which involve users in the process of identifying usability problems, include observations, questionnaires, and interviews.

With the fast development of the Internet, the increasing use of www as an information-seeking, and the increasing number of educational websites, the importance of universities' websites increased. Nowadays, academic websites become a vital part of academic institutions, and one of their most visible faces [3]. Research indicated that educational websites aim to: Recruit major stakeholders of academic institutions (i.e. prospective students, prospective faculty, alumni, parents) [4-6], provide a cost effective, and timely communication with their stakeholders [7], and provide a way to present their image on the Internet (i.e. academic offering, programs, services, students resources) $[4,5,7]$. In order to achieve the mentioned aims, and to respond to the new generation of students whom grown up with technology, educational websites should consider usability while making and improving their websites. Addressing the usability of educational websites could help students to enjoy the learning experience, increase students' confidence, and encourage students to use the website [8]. Unfortunately, a university website design is often based on the perceptions of web designers, and/or managers in a university instead of students' needs.

Despite the importance of making educational websites usable, few studies were found in the literature that evaluated the usability of such sites, specifically in the context of Arabic websites. The studies that were found employed usability methods, including heuristic evaluation, to evaluate the usability of educational websites [4, 6, 9-11]. However, these studies did not provide details regarding specific types of usability problems that could be found on educational websites.

The aim of this research is to employ the heuristic evaluation method in order to identify common usability problem areas that could be found on Jordanian university websites.

This paper is organized as follows. Section two presents related work. Section three presents the methodology used by this research. Section four presents the results and discussions, and finally section five concludes the paper

\section{RELATED WORK}

This section reviews studies that evaluated the usability of educational sites. These studies employed various usability methods in the process of identifying usability problems. Astani and Elhindi [4], for example, employed the heuristic evaluation method to evaluate the usability of the top 50 colleges and universities. The authors indicated that the tested websites had usability problems related mainly to old content and inappropriate layout.

Noiwan and Norcio [9] also evaluated and compared the usability of two Thai and two US academic websites, using web usability checklist that aimed to measure the usability indexes of the sites. The results showed that the sites had 
several usability problems including: Lack of a site map, old content, lack of navigational tools, and inconsistency problems. The results also showed that the Thai websites have additional problems, such as: Ineffective internal search functions and language problems (i.e. misspelling words).

Similarly, Kostaras and Xenos [10] employed the heuristic evaluation method to evaluate the usability of the website of the Hellenic Open University using the ten usability heuristics suggested by Nielsen [12]. They identified only 38 usability problems on the university website related to: Lack of navigational support links, inconsistency problems (i.e. a variation of font sizes was used), errors in the internal search function, and inappropriate design of menu.

Furthermore, Toit and Bothma [11] investigated the usability of the website of an academic marketing department in the University of South Africa, using the heuristic evaluation method. They mentioned only few examples regarding the usability problems that were identified on the website, which related to: Poor navigation, old content, and incomplete information regarding the modules of the department.

Pierce [6], however, employed heuristic evaluation, and user testing methods to evaluate the usability of Harvard University website. The results identified some usability problems on the site, related mainly to: Lack of navigational tools, inconsistency problems, and inappropriate design of the home page.

Other studies were found in the literature which employed users in the evaluation and identification of usability problems on educational websites. Kasil and Aucikurt [13], for example, employed 54 students to investigate 132 websites of tourism departments at universities in Turkey. The results showed that most of the sites: Did not present updated information, did not have an internal search function, did not present their content in foreign languages, and did not display important information (i.e. academic calendar, FAQ, programs).

Similarly, Christoun et al. [14] investigated students' overall satisfaction with an academic website, with regard to its technology, usability, aesthetic, and content using an online questionnaire. The results showed that only $53.4 \%$ of the students agreed that the search function of the site was effective, and $66 \%$ agreed that it was easy to find information.

Few studies were found in the literature regarding Arabic websites. The study conducted by Mustafa and Al-Zoua'bi [15] is an example. They employed a questionnaire to evaluate the usability of nine Jordanian university websites, by 252 students. The results showed that the overall usability level of the websites was acceptable. However, there were some weaknesses in some aspects of the sites, related to design, interface, and performance. However, the study didn't provide details regarding specific types of usability problems that users identified on the university sites.

Similarly, Hasan [16] asked 237 students to provide ratings for nine Jordanian university websites using usability criteria. The students were also asked to report qualitatively what they liked, and disliked regarding the design of the websites. The results showed that the common weaknesses on the websites include: The design of the sites, the fact that most of the sites were inconsistent, in terms of: Colors, fonts, the Arabic and English language interface, and the design of the pages, and the lack of support to Arabic language.

The literature outlines above proved the usefulness of the heuristic evaluation and questionnaire methods regarding their ability to identify various types of usability problems on educational websites. They provide important information regarding types of usability problem that could be found on educational websites. However, the studies, which employed the heuristic evaluation method in the identification of usability problems, provide few number of usability problems, with little details.

\section{METHODOLOGY}

Three Jordanian university websites were selected, which had the highest ranking for the year 2011 at one of the major international university ranking websites, which is Eduroute [17]. The universities were: Hashemite University, the University of Jordan, and Yarmouk University. These universities are large public universities with a variety of disciplines.

In order to evaluate the usability of the selected university websites using the heuristic evaluation method, two documents were developed: Heuristic guidelines, and a list of tasks. The heuristic guidelines document includes a set of comprehensive heuristics, specific to educational websites, which was developed earlier by Hasan $[16,18]$, and used as criteria in the evaluation of educational websites in Jordan. The adopted heuristics were organized into five major categories. Table 1 displays the categories, and subcategories of the adopted heuristics.

TABLE 1. The categories and subcategories of the adopted heuristic guidelines.

\begin{tabular}{|l|l|}
\hline \multicolumn{1}{|c|}{ Category } & \multicolumn{1}{c|}{ Subcategories } \\
\hline Navigation & $\begin{array}{l}\text { Navigation support; effective } \\
\text { internal search; working links; } \\
\text { no broken links; no orphan } \\
\text { pages. }\end{array}$ \\
\hline \multirow{3}{*}{ Architecture/organization } & $\begin{array}{l}\text { Logical structure of site; no } \\
\text { deep architecture; simple } \\
\text { navigation menu. }\end{array}$ \\
\hline \multirow{5}{*}{ Eesign of use and communication } & $\begin{array}{l}\text { Quick downloading of web } \\
\text { pages; easy interaction with a } \\
\text { website; contact us }\end{array}$ \\
& $\begin{array}{l}\text { information; foreign language } \\
\text { support. }\end{array}$ \\
\hline Content & $\begin{array}{l}\text { Aesthetic design; appropriate } \\
\text { use of images; appropriate } \\
\text { choice of fonts; appropriate } \\
\text { choice of colors; appropriate } \\
\text { page design; consistency. }\end{array}$ \\
\hline & $\begin{array}{l}\text { Up-to-date information; } \\
\text { relevant information; no } \\
\text { under-construction pages; } \\
\text { accurate Information; } \\
\text { information about the } \\
\text { university; information about } \\
\text { the faculty; information about } \\
\text { the departments. }\end{array}$ \\
\hline
\end{tabular}


The list of tasks document includes ten tasks, which represent the pages students visit usually on a university website. Those pages represent the findings obtained from an analysis of a questionnaire that aimed to investigate the types of pages visited by 237 students on a university website. The questionnaire was provided to students from various departments at one of the universities in Jordan as part of this research. The results found that the most frequently visited pages by students were: Academic calendar; university announcements / news; deanship of student affairs; student services; admission and registration; available courses (current and/or next); faculties; departments; study plans, and academic staff.

Five evaluators participated in this research; two usability specialists, and three web experts. The evaluators were asked to visit all pages included in the list of tasks, and to use the heuristic guidelines while evaluating each website. They were also asked to visit all pages related to all faculties, and their corresponding departments on each of the studied universities' websites. The evaluation was done independently by each evaluator, and completed over four months (May 2012 to August 2012).

The heuristic evaluators' comments on the compliance of each site to each heuristic principle were grouped together for each site, and categorized under the categories and subcategories of the heuristic guidelines. Each heuristic subcategory of each website was examined to identify problems with each site. These problems were classified, and similar problems were grouped together to identify common areas of usability problems on each website. These were examined to identify common areas of usability problems across the three websites. Consequently, 34 common areas of usability problems were identified, which suggested identifying 34 problem sub-themes. These 34 problem sub-themes suggested identifying four main problem themes, based on the types of the identified problems. The four main problem themes related to: Navigation, design, content, and ease of use and communication. The list of problem themes and sub-themes is explained in the results.

\section{RESULTS AND DISCUSSION}

This section presents the main results and discusses them in the light of the related literature. It includes four subsections which explain, with regards to the four main problem themes, the type and number of specific usability problems identified on the sites.

\section{A. Navigational Problems}

Seven common navigational problems were identified on the websites, as shown in Table 2:

- The first problem is related to weak navigational support. These concerned mainly with pages on the websites, related specifically to various faculties and/or departments, which did not have a navigational menu, or links to return back to the corresponding faculty and/or department.
- The second problem is concerned with misleading links, where large numbers of such problem were found on the websites of Hashemite University and Yarmouk University. For example, the link related to the name of the chairman (for all the departments of Hashemite University) opened a page that was not expected by the evaluators; it opened a page that displays an introduction to the department instead of information about the chairman of the department.

- The third problem is related to links that do not open the destination pages. For example, the admission and research link, which was located at the home page of some faculties of Hashemite University, don't open the corresponding destination pages. They remain on the same page (the home page).

- The fourth problem is related to links, which when selected, caused the disappearance of the main menu or part of it. For example, selecting the back to top link (at the introduction page of Yarmouk University website), caused the disappearance of the corresponding department menu.

- The fifth problem is related to broken links. It was found that the website of Hashemite University had the largest number of this problem, compared to the other websites.

- The sixth problem is related to orphan pages. The results showed that the website of Yarmouk University had the largest number of such problem, compared to the other websites.

- The seventh problem is concerned with ineffective internal search. The results showed that all the websites had problems with the internal search functions, related to the different universities' sub sites investigated during this research.

TABLE 2. Common usability problem sub-themes related to navigation.

\begin{tabular}{|l|c|c|c|}
\hline \multicolumn{1}{|c|}{$\begin{array}{c}\text { Navigational } \\
\text { Problems }\end{array}$} & $\begin{array}{c}\text { Hashemite } \\
\text { University }\end{array}$ & $\begin{array}{c}\text { The } \\
\text { University } \\
\text { of Jordan }\end{array}$ & $\begin{array}{c}\text { Yarmouk } \\
\text { University }\end{array}$ \\
\hline $\begin{array}{l}\text { 1. Weak } \\
\text { navigational support }\end{array}$ & 278 & 17 & 333 \\
\hline 2. Misleading links & 172 & 49 & 342 \\
\hline $\begin{array}{l}\text { 3. Links do not open } \\
\text { the destination pages }\end{array}$ & 46 & 20 & 75 \\
\hline $\begin{array}{l}\text { 4. Links cause } \\
\text { disappearance of the } \\
\text { menu }\end{array}$ & 0 & 29 & 36 \\
\hline 5. Broken links & 529 & 208 & 21 \\
\hline 6. Orphan pages & 15 & 6 & 220 \\
\hline $\begin{array}{l}\text { 7. Ineffective } \\
\text { internal search }\end{array}$ & $\mathbf{1 0 4 3}$ & $\mathbf{3 3 3}$ & $\mathbf{1 0 3 3}$ \\
\hline $\begin{array}{l}\text { Total no. of } \\
\text { navigational } \\
\text { problems }\end{array}$ & & & 6 \\
\hline
\end{tabular}




\section{B. Design Problems}

18 usability problems were identified on the websites regarding design, as shown in Table 3. Those problems concerned four major issues: Inconsistency (problems no. 19); inappropriate page design (problems no. 10-15); problems with the use of images (problems no. 16-17), and problems with the choice of colors (problem no. 18):

- Nine specific inconsistency problems were identified on the websites (Table 3, problems no. 1-9). Examples of the inconsistency problems are shown in Table 3.

- Six problems were found on the sites concerned inappropriate design of their pages (Table 3, problems no. 10-15). For example, the results showed that all the websites had large number of ineffective text format of the sites' pages, where information, figures, and tables were not aligned correctly (Table 3 ). Other problems related to inappropriate orientation of the page design, pages without headings or with inappropriate headings, and short or very long pages.

- Another two specific types of problems were found on the sites related to inappropriate use of images: Poor quality of images, and broken images (Table 3, problems no. 16-17).

- The last problem is related to inappropriate choice of color, and was identified on Hashemite University, and the University of Jordan websites (Table 3, problem no. 18$)$.

TABLE 3. Common usability problem sub-themes related to design.

\begin{tabular}{|c|c|c|c|}
\hline Design Problems & $\begin{array}{l}\text { Hashemite } \\
\text { University }\end{array}$ & $\begin{array}{c}\text { The } \\
\text { University } \\
\text { of Jordan } \\
\end{array}$ & $\begin{array}{r}\text { Yarmouk } \\
\text { University }\end{array}$ \\
\hline $\begin{array}{l}\text { 1. Inconsistency in } \\
\text { the language of the } \\
\text { interface }\end{array}$ & 140 & 138 & 109 \\
\hline $\begin{array}{l}\text { 2. Inconsistency in } \\
\text { the font case (capital } \\
\text { and small) }\end{array}$ & 163 & 76 & 6 \\
\hline $\begin{array}{l}\text { 3. Inconsistency in } \\
\text { the font size }\end{array}$ & 19 & 50 & 84 \\
\hline $\begin{array}{l}\text { 4. Inconsistency in } \\
\text { the font style (regular } \\
\text { and bold) }\end{array}$ & 59 & 18 & 76 \\
\hline $\begin{array}{l}\text { 5. Inconsistency in } \\
\text { the content }\end{array}$ & 10 & 28 & 15 \\
\hline $\begin{array}{l}\text { 6. Inconsistency in } \\
\text { the alignment of the } \\
\text { header }\end{array}$ & 2 & 19 & 4 \\
\hline $\begin{array}{l}\text { 7. Inconsistency in } \\
\text { the font color }\end{array}$ & 13 & 31 & 0 \\
\hline $\begin{array}{l}\text { 8. Inconsistency in } \\
\text { the design }\end{array}$ & 12 & 0 & 0 \\
\hline $\begin{array}{l}\text { 9. Inconsistency in } \\
\text { the size of images }\end{array}$ & 0 & 0 & 52 \\
\hline $\begin{array}{l}\text { 10. Inappropriate } \\
\text { orientation of the } \\
\text { page design }\end{array}$ & 60 & 0 & 179 \\
\hline $\begin{array}{l}\text { 11. Inappropriate } \\
\text { design of main menu }\end{array}$ & 39 & 101 & 113 \\
\hline $\begin{array}{l}\text { 12. Ineffective text } \\
\text { format }\end{array}$ & 925 & 457 & 427 \\
\hline
\end{tabular}

\begin{tabular}{|l|c|c|c|}
\hline $\begin{array}{l}\text { 13. Inappropriate/ not } \\
\text { representative } \\
\text { heading of a page }\end{array}$ & 95 & 432 & 142 \\
\hline 14. Long pages & 2 & 5 & 149 \\
\hline 15. Short pages & 57 & 19 & 29 \\
\hline $\begin{array}{l}\text { 16. Inappropriate } \\
\text { quality of images }\end{array}$ & 30 & 532 & 2 \\
\hline $\begin{array}{l}\text { 17. Broken images } \\
\text { 18. Inappropriate } \\
\text { choice of color }\end{array}$ & 57 & 28 & 0 \\
\hline $\begin{array}{l}\text { Total no. of design } \\
\text { problems }\end{array}$ & $\mathbf{1 6 8 3}$ & $\mathbf{1 9 3 4}$ & $\mathbf{1 4 1 6}$ \\
\hline
\end{tabular}

\section{Content Problems}

Seven common usability problems were identified on the websites regarding content, as shown in Table 4:

- The first problem is related to old information, which was presented on pages related to Hashemite University and the University of Jordan websites.

- The second problem is related to incomplete information. The results show that all the websites had large number of such problem (i.e. faculty staff pages).

- The third problem is related to links that open DOC and/or PDF files, but there is no information regarding the type of file a link opened.

- The fourth problem is related to empty pages, where the University of Jordan website had the largest number of this problem, compared to the other two websites.

- The fifth problem is related to inappropriate content problems. Examples on these problems: Crowded pages, repetition of content, and very concise content.

- Finally, the results identified two specific types of problems related to grammatical accuracy: Punctuation and grammatical errors (the sixth and seventh problems at Table 4, respectively).

TABLE 4. Common usability problem sub-themes related to content.

\begin{tabular}{|l|c|c|c|}
\hline \multicolumn{1}{|c|}{ Content Problems } & $\begin{array}{c}\text { Hashemite } \\
\text { University }\end{array}$ & $\begin{array}{c}\text { The } \\
\text { University } \\
\text { of Jordan }\end{array}$ & $\begin{array}{c}\text { Yarmouk } \\
\text { University }\end{array}$ \\
\hline 1. Old information & 68 & 41 & 0 \\
\hline $\begin{array}{l}\text { 2. Incomplete } \\
\text { information }\end{array}$ & 344 & 158 & 463 \\
\hline $\begin{array}{l}\text { 3. No information } \\
\text { regarding the type of a } \\
\text { file that a link will } \\
\text { open }\end{array}$ & 59 & 0 & 227 \\
\hline $\begin{array}{l}\text { 4. Empty page } \\
\text { 5. Inappropriate } \\
\text { content }\end{array}$ & 444 & 80 & 62 \\
\hline 6. Punctuation errors & 272 & 39 & 13 \\
\hline $\begin{array}{l}\text { 7. Grammatical } \\
\text { accuracy problems }\end{array}$ & 18 & 11 & 2 \\
\hline $\begin{array}{l}\text { Total no. of content } \\
\text { problems }\end{array}$ & $\mathbf{1 3 7 8}$ & $\mathbf{5 7 1}$ & $\mathbf{9 1 5}$ \\
\hline
\end{tabular}




\section{Ease of Use and Communication Problems}

Two usability problems were identified on the websites regarding ease of use and communication, as shown in Table 5:

- The first problem is related to being not easy to interact with the websites, in order to visit some pages.

- The second problem is related to the lack of support to the Arabic language. The results show that the websites of Hashemite University and the University of Jordan had problems related to the fact that they did not support the Arabic language. The language interface of the Hashemite University website, including its 13 faculties and their corresponding departments, was written only in English language. Regarding the University of Jordan website, it was found that most of its faculties (16 out of 18) and their corresponding departments were presented using only English language. However, Yarmouk University website presents the university faculties and their corresponding departments using Arabic and English languages.

TABLE 5. Common usability problem sub-themes related to ease of use and communication.

\begin{tabular}{|l|c|c|c|}
\hline $\begin{array}{l}\text { Ease of Use and } \\
\text { Communication } \\
\text { Problems }\end{array}$ & $\begin{array}{c}\text { Hashemite } \\
\text { University }\end{array}$ & $\begin{array}{c}\text { The } \\
\text { University } \\
\text { of Jordan }\end{array}$ & $\begin{array}{c}\text { Yarmouk } \\
\text { University }\end{array}$ \\
\hline $\begin{array}{l}\text { 1. Difficult } \\
\text { interaction with } \\
\text { a website }\end{array}$ & 8 & 3 & 35 \\
\hline $\begin{array}{l}\text { 2. Not } \\
\text { supporting more } \\
\text { than one } \\
\text { language }\end{array}$ & 64 & 85 & 0 \\
\hline $\begin{array}{l}\text { Total no. of } \\
\text { ease of use and } \\
\text { communication } \\
\text { problems }\end{array}$ & $\mathbf{7 2}$ & $\mathbf{8 8}$ & $\mathbf{3 5}$ \\
\hline
\end{tabular}

This research addressed a gap noted in the literature, with regard to lack of identification of specific types of usability problems found by heuristic evaluation methods on educational websites, specifically in Jordan. Earlier research, which evaluated the usability of educational websites, provided only few examples of the usability problems that were identified by the heuristic evaluation method [4, 6, 9-11].

This research, however, uniquely identified large number of usability problems, related to 34 specific types of usability problems that could be found on an educational website. It also presented the frequency number of these problems on each of the tested website. This is related to the fact that this research used the qualitative data obtained from the heuristic evaluators, who comprehensively investigated large number of pages on the three selected Jordanian university websites, in the process of identifying the usability problems.

Despite the fact that the results of this research involved providing more detailed descriptions of usability problems that were identified by the heuristic evaluation compared to the previous research, it was found that there was an agreement between the results of this research, and the results of the previous studies. Earlier research, specifically, identified the following usability problems on educational websites from the view point of evaluators: Old content [4, 9, 11], lack of navigational support $[6,9-11]$, inconsistency problems $[6,9$, 10], ineffective internal search [9, 10], language problems [9], inappropriate page design [4, 6], incomplete information [11], and inappropriate design of menus [10]. These were also confirmed by the results of this research. Furthermore, the results of this research provide information regarding additional problems that were uniquely identified in this research. These included: Misleading links, links don't open the destination pages, links cause disappearance of the menu, broken links, various types of inconsistency problems, inappropriate orientation of the page design, ineffective text format, broken images, inappropriate choice of color, empty page, inappropriate content, difficult interaction with a website, and lack of support to the Arabic language.

The large number of common and specific usability problems that were uniquely identified in this research on the Jordanian universities' websites, could be used as guidelines for universities in Jordan, to investigate and improve their universities' websites, and therefore to achieve the advantages of usable educational websites.

\section{CONCLUSIONS}

This research comprehensively evaluated the usability of three large public university websites in Jordan, using the heuristic evaluation method. The results identified a list of 34 specific types of common usability problems that were found on the selected Jordanian university websites, and described the frequency number of these problems.

The results are useful for managers, designers, and/or evaluators of universities' websites in Jordan, who are willing to evaluate and improve the design of their websites. Despite the fact that this research was conducted in Jordan, it is likely that the results can be useful to other countries. The 34 specific types of common usability problems that were identified in this research provide guidance for educational institutions regarding website features, which should be taken into consideration while designing and/or evaluating their websites.

\section{ACKNOWLEDGMENT}

The authors would like to thank the web experts who participated in this study: Abla HerzAllah, Amneh Alamleh, and Ayat Damra. Their enthusiasm is greatly appreciated.

\section{REFERENCES}

[1] ISO 9241-11, International Standard First Edition. Ergonomic Requirements for Office Work with Visual Display Terminals (VDTs), Part11: Guidance on Usability, 1998. <http://www.idemployee.id.tue.nl/g.w.m.rauterberg/lecturenotes/ISO924 1 part11.pdf $>$, [accessed 03.04.2007].

[2] Nielsen J. and Molich R., "Heuristic Evaluation of User Interfaces", in the Proceedings of CHI'90, ACM, pp. 249-256, 1990.

[3] Peterson K., "Academic Web Site Design and Academic Templates: Where does the Library Fit in?", Information Technology and Libraries, Vol. 25, No.4, pp. 217-221, December 2006. 
[4] Astani M. and Elhindi M., "An Empirical Study of University Websites", Issues in Information Systems, Vol. IX, No. 2, pp. 460-465, 2008.

[5] Astani M., "An Empirical Study of the Effectiveness of Universities' Web Sites", in the Proceedings of IACIS, 2003.

[6] Pierce K., "Web Site Usability Report for Harvard University", Technical Report, Capella University, 2005.

[7] Mentes A. and Turan A., "Assessing the Usability of University Websites: An Empirical Study on Namic Kemal University", the Turkish Online Journal of Educational Technology, Vol. 11, No. 3, pp. 61-69, 2012.

[8] Lencastre J. and Chaves J., "A Usability Evaluation of Educational Websites", in the Proceedings of EADTU Conference, 2008.

[9] Noiwan J. and Norcio A., "A Comparison Analysis on Web Heuristic Usability between Thai Academic Web Sites and US Academic Web Sites", in the Proceedings of SGI, World Multi Conference on Systems, Cybermetrics and Informatics, Volume X, Concepts and Applications of Systems, Cybermetrics and Informatics, Orlando, Florida, USA, 2000.

[10] Kostaras N. and Xenos M., "Assessing Educational Web-site Usability using Heuristic Evaluation Rules", in the Proceedings of 11th Panhellenic Conference in Informatics, 2006.

[11] Toit M. and Bothma C., "Evaluating the Usability of an Academic Marketing Department's Website from a Marketing Student's Perspective", International Retail and Marketing Review, Vol. 5, No. 1, pp. 15-24, 2010.

[12] Nielsen J., "Heuristic Evaluation", In Nielsen J. \& Mack R. L. (Eds.), Usability Inspection Methods, John Wiley \& Sons, New York, 25-64, 1994.

[13] Kasli M. and Avcikurt C., "An Investigation to Evaluate the Websites of Tourism Departments of Universities in Turkey", Journal of Hospitality, Leisure, Sport \& Tourism Education, Vol. 7, No., 2, pp. 7792, 2008.

[14] Christoun S., Aubin H., Hannon C., and Wolk R., "Web Site Usability in Higher Education", Information Systems Education Journal, Vol. 4, No. 110, 2006.

[15] Mustafa S. and Al-Zoua'bi L., "Usability of the Academic Websites of Jordan's Universities", in the Proceedings of the International Arab Conference on Information Technology, Tunisia, 2008..

[16] Hasan L., "Evaluating the Usability of Nine Jordanian University Websites", in the Proceedings of the $2^{\text {nd }}$ International Conference on Communications and Information Technology (ICCIT), Hammamet, Tunisia, pp. 102-107, 26-28 June, 2012.

[17] Eduroute, < http://www.eduroute.inf> [accessed 20.03.2011].

[18] Hasan L., "Investigating the Relative Importance of Design Criteria in the Evaluation of the Usability of Educational Websites from the Viewpoint of Students", in the Proceedings of the World Congress on Engineering (WCE 2012 ), Vol II, London, UK, 4-6 July, 2012.

\section{Creative Commons Attribution License 4.0 (Attribution 4.0 International, CC BY 4.0)}

This article is published under the terms of the Creative Commons Attribution License 4.0 https://creativecommons.org/licenses/by/4.0/deed.en_US 